Article details

Article title: Bilingualism and Multilingualism in the Roman World

Article ID: 9780195389661-0197

Article author(s): Alex Mullen

Publishing Group: Reference-US

$\square$ Revision (XML provided)

Title revised? Y/N

Previous title:

Table of contents:

Introduction

General Overviews

General Surveys of Languages

Modern Bilingualism Studies

Regional Studies

Rome and Italy

Sicily

Iberian Peninsula

Gaul

Britain

Germanies and Eastern Europe

Greece and Asia Minor

Egypt

North Africa

Near East

Attitudes toward Language and Language Policy

Greek and Other Languages in Latin Literature

Translation Literature

"Roman Greek"

Technical Linguistic Studies

Lexical Contact-Induced Change (Loanwords)

Non-lexical Contact-Induced Change

Style and XML details

Citation style: Scientific

Special characters/fonts/elements:

Module details

Module: Classics Module code: CLA

Module ISBN:

9780195389661

Format neutral

Note: All content will be format neutral compliant, unless otherwise indicated here Exceptions:

- Oxford Bibliographies articles do not currently have keywords. Introductions serve 
as abstracts.

\section{BILINGUALISM AND MULTILINGUALISM IN THE ROMAN WORLD}

\section{INTRODUCTION}

Roman authors referred to Latin and Greek as utraque lingua (both our languages), and the study of Classics has traditionally entailed an appreciation of the entanglement and complex relations between Latin and Greek language and literature. However, the Roman world was linguistically diverse - multilingual, not bilingual. Especially since the pioneering work of James Adams (Adams 2003, cited under *General Overviews*), classicists have begun to engage more fully with modern bi- and multilingualism theory and practice and to explore more systematically beyond Latin and Greek, literature, and the elite. This article is designed to introduce some of the key scholarship in this rapidly expanding and important field, presenting not only recent works, but also some of the earlier research that remains influential. It begins with a selection of general overviews, which characterize the new wave and more traditional approaches. It then offers a short selection of general surveys of languages in the Roman world and introductory, influential texts in modern bilingualism studies. The rest of the article is split loosely between epigraphic regional studies, literary bilingualism, and technical linguistic studies. Discussion in the *Regional Studies* section makes it clear that some areas (e.g., Egypt) have a long tradition of investigation into bi- and multilingualism, whereas others remain relatively under-researched. In the largely literary sections, the focus is on *Greek and Other Languages in Latin Literature*, *Translation Literature*, and *"Roman Greek"*, which concentrates on the Greek of Roman writers and also considers epigraphic sources such as the senatus consulta. In these sections the viewpoint is primarily on bi- and multilingualism in literary and related sources and does not seek to encompass the wider literary scholarship. The final section, *Technical Linguistic Studies*, contains research related to both lexical and non-lexical contact phenomena.

\section{GENERAL OVERVIEWS}

This section contains two books written by the leading expert, James Adams, of which the first-Adams 2003 - should be essential reading for any aspect of bilingualism in the Roman world. Also included are three multiauthored volumes, two of which are wide-ranging (Adams, et al. 2002; Mullen and James 2012), and a third restricted to epigraphy (Biville, et al. 2008). Of more historical than linguistic perspective are the monographs by Kaimio 1979 and Rochette 1997 (the first with a predominantly Western focus; the latter, Eastern). Two short articles offer brief overviews and further bibliography; the emphasis of Mullen 2011 is more epigraphical and that of Rochette 2010 more literary.

Adams, James N. 2003. Bilingualism and the Latin language. Cambridge, UK: Cambridge Univ. Press. [ISBN: 9780521817714]

If this article had to reference only one book, this would be it. Adams uses modern bi- and multilingualism research and systematically includes non-classical languages and non-elite, non-literary sources. Unsurpassed in terms of breadth and insight.

Adams, James N. 2007. The regional diversification of Latin 200 BC-AD 600. Cambridge, UK: Cambridge Univ. Press. [ISBN: 9780521881494]

The second of Adams's trio of "big books" that have revolutionized our understanding of Latin (the third being Social Variation and the Latin Language [Cambridge, UK: Cambridge Univ. Press, 2013]). This has less direct relevance for bilingualism than does Adams 2003, but it still has numerous sections that should be consulted by those interested in language contact. The focus is on the Western Empire. 
Adams, James N., Mark Janse, and Simon Swain. 2002. Bilingualism in ancient society: Language contact and the written text. Oxford: Oxford Univ. Press. [ISBN: 9780199245062]

An extremely wide-ranging volume with a particularly helpful introduction by Adams and Swain (pp. 1-20) and another very useful introductory offering by Langslow (pp. 23-51) that approaches bilingualism in corpus languages. Among a series of stellar chapters, that on code-switching in Cicero by Swain (pp. 128-167) stands out and provides a wonderful complement to the section on Cicero in Adams 2003 (pp. 308-347).

Biville, Frédérique, Jean-Claude Decourt, and Georges Rougemont, eds. 2008. Bilinguisme gréco-latin et épigraphie: Actes du colloque organisé à l'Université Lumière-Lyon 2 . . les 17, 18 et 19 mai 2004. Lyon, France: Maison de l'Orient Méditerranéen. [ISBN: 9782356680006] [class:conference-proceeding]

A conference volume, this time with a focus specifically on epigraphy. Although both East and West are covered, it is weighted toward the former; in the section on the West, only one paper (Decourt on Gaul, pp. 305-319) does not concern the Res gestae or Italy. Some papers do not engage with key work, e.g., Adams 2003.

Kaimio, Jorma. 1979. The Romans and the Greek language. Helsinki: Societas Scientiarum Fennica. [ISBN: 9789516530881]

A broad synthesis that claims to be sociolinguistic, but is really historical and literary. A useful place to start and commonly cited, but to be treated with some caution (see, e.g., the review by Michel Dubuisson, "La place du grec dans la société romaine: À propos d'un ouvrage récent," in Revue Belge de Philologie 63.1 [1985]:108-115).

Mullen, Alex. 2011. Latin and other languages: Societal and individual bilingualism. In $A$ companion to the Latin language. Edited by James Clackson, 527-548. Malden, MA, and Oxford: Wiley-Blackwell. [ISBN: 9781405186056]

A helpful general introduction, which ranges across literary and nonliterary sources, and should be read with Rochette 2010.

Mullen, Alex, and Patrick James, eds. 2012. Multilingualism in the Graeco-Roman worlds. Cambridge, UK: Cambridge Univ. Press. [ISBN: 9781107013865]

Another extremely wide-ranging volume extending across disciplinary and temporal boundaries (including, e.g., archaeological perspectives and the Graeco-Roman world of the medieval mind).

Rochette, Bruno. 1997. Le latin dans le monde grec: Recherches sur la diffusion de la langue et des lettres latines dans les provinces hellénophones de l'Empire romain. Brussels:

Collection Latomus. [ISBN: 9782870311738]

An important book, which serves as a reference work especially for historical aspects of Greek-Latin bilingualism. After an extensive introduction, chapter 1 discusses Latin in official relations with the East and in the public life of the Greek-speaking provinces, chapter 2 treats Latin in the education of the eastern provinces, chapter 3 presents a prosopographical study of Greeks known for their knowledge of Latin, and chapter 4 tackles Latin literature in the Greek world. Extensive bibliography.

Rochette, Bruno. 2010. Greek and Latin bilingualism. In A companion to the Greek language. Edited by Egbert J. Bakker, 281-293. Malden, MA, and Oxford: Wiley-Blackwell. [ISBN: 9781405153263]

A helpful general introduction, especially to the literary evidence, though with some questionable points. Weinreich 1953 (Languages in contact: findings and problems. New York: Publications of the Linguistic Circle of New York) is the only modern sociolinguistic text cited, although it is now outdated, especially in its views on code-switching. 


\section{GENERAL SURVEYS OF LANGUAGES}

General surveys of languages remain an overlooked aspect of the scholarship. Definitive and up-to-date surveys of the linguistic complexity of the Roman world in print form are perhaps unrealistic; the examples listed here are the best available since the 1980s. Harris 1989, Langslow 1988, Neumann and Untermann 1980, and Polomé 1983 were all published in the 1980s. Woodard 2004 is more recent, although it does not replace, e.g., Neumann and Untermann 1980. The online resource **Trismegistos** provides a handy list of languages and scripts of the ancient world, which is constantly updated and links to relevant databases and other online information.

Harris, William V. 1989. Ancient literacy. Cambridge, MA: Harvard Univ. Press. [ISBN: 9780674033801] Includes a brief survey of the languages of the Graeco-Roman world (pp. 175-190). Now out of date in many respects, it is still a useful reference given that the volume itself is a regular on many classicists' shelves.

Langslow, David. 1988. Languages and dialects. In Civilization of the ancient Mediterranean: Greece and Rome. Vol. 1. Edited by Michael Grant and Rachel Kitzinger, 183-207. New York: Scribner. [ISBN: 9780684175942]

An authoritative survey for non-specialists of the languages spoken in the Greek and Roman worlds. Very basic bibliography.

Neumann, Günter, and Jürgen Untermann, eds. 1980. Die Sprachen im römischen Reich der Kaiserzeit: Kolloquium vom 8.-10. April 1974. Cologne: Rheinland Verlag. [ISBN: 9783792704318] [class:conference-proceeding]

An impressively comprehensive set of chapters in German surveying the languages in the Roman Empire. Several of the chapters focus on specific regions (e.g., de Simone on Italy (pp. 65-81)); others are differently delineated (e.g., minority groups and their languages in Rome by Kajanto (pp. 83-101), the role of Greek in the Empire by Zgusta (pp. 121-145), Jews and Syrians in the Empire by Solin (pp. 301-330), and Vulgar Latin by Tovar (pp. 331-342)). This volume now requires updating but remains a useful place to start for overviews and bibliography.

Polomé, Edgar C. 1983. The linguistic situation in the Western Provinces of the Roman Empire. In Aufstieg und Niedergang der römischen Welt II.29. Edited by Hildegard Temporini and Wolfgang Haase, 509-553. Berlin: Walter de Gruyter. [ISBN: 9783110103762]

Clear survey of the linguistic situation in the Roman West. Good bibliography for pre-1980 works.

*Trismegistos[http://www.trismegistos.org/]*. [class:dataSet-database]

A fantastic resource, initially set up to cover the papyrological and epigraphic materials of Egypt and the Nile Valley between roughly 800 BCE and $800 \mathrm{CE}$, but now taking in the ancient world more generally. Offers its own databases and also acts as a platform to access a wide range of resources in different ancient languages. The succinct survey under the section "Languages and Scripts of the Ancient World" is a good first port of call to access basic information and databases.

Woodard, Roger, ed. 2004. The Cambridge encyclopedia of the world's ancient languages. Cambridge, UK: Cambridge Univ. Press. [ISBN: 9780521562560] Useful linguistic survey of over forty ancient languages. After an introductory chapter by Woodard, contributors present each language in turn, giving information about major grammatical and syntactical features, developments, contextual information, and bibliography. Some, although fairly limited, information about interactions between different languages. 


\section{MODERN BILINGUALISM STUDIES}

The field of modern bi- and multilingualism studies is vast. The major conferences attract thousands, and output is staggering. Nonetheless, relatively few general, book-length treatments are available, and certain key articles are constantly cited. The ones included here are regularly used by researchers of the ancient world and serve as useful starting points. Ferguson 1959 and Fishman 1967 consider diglossia; Fishman 1964 explores language maintenance and shift; Fishman 1965 discusses language choice; Gardner-Chloros 2009 and Milroy and Muysken 1995 focus on code-switching (the full-blown switch between languages within an utterance or piece of writing); Thomason and Kaufman 1988 considers language contact; Hamers and Blanc 2000, Myers-Scotton 2006, and Thomason 2001 are general works. Thomason 2001 and Myers-Scotton 2006 are the best places to begin in this diverse field.

Ferguson, Charles A. 1959. Diglossia. Word 15:325-340.

A seminal discussion of "diglossia," a concept sometimes used by classicists without due care and attention. See also Fishman 1967.

Fishman, Joshua A. 1964. Language maintenance and language shift as a field of inquiry. Linguistics 9:32-70.

The first of three seminal articles by a scholar who helped to set the parameters of the field of sociolinguistics. This article focuses on language maintenance versus language shift in situations of language contact.

Fishman, Joshua A. 1965. Who speaks what language to whom and when? La linguistique 1.2: $67-88$.

The second of Fishman's seminal articles deals with key sociolinguistic aspects of the use of more than one language.

Fishman, Joshua A. 1967. Bilingualism with and without diglossia; Diglossia with and without bilingualism. Journal of Social Studies 23.2: 29-38.

The third of Fishman's articles models bilingualism and diglossia, making it absolutely clear that diglossia and bilingualism ought not to be used interchangeably.

Gardner-Chloros, Penelope. 2009. Code-switching. Cambridge, UK: Cambridge Univ. Press. [ISBN: 9780521862646]

A concise volume covering all aspects of code-switching.

Hamers, Josiane F., and Michel H. A. Blanc. 2000. Bilinguality and bilingualism. Cambridge, UK: Cambridge Univ. Press. [ISBN: 9780521648431]

A rewarding and wide-ranging book on individual bilingualism (or "bilinguality") and societal bilingualism from both sociolinguistic and psycholinguistic perspectives.

Milroy, Leslie, and Pieter Muysken, eds. 1995. One speaker, two languages: Crossdisciplinary perspectives on code-switching. Cambridge, UK: Cambridge Univ. Press. [ISBN: 9780521473507]

Chapters by leading scholars on different aspects of code-switching: institutional and community settings, social life, grammatical constraints, bilingual development, and processing.

Myers-Scotton, Carol. 2006. Multiple voices: An introduction to bilingualism. Malden, MA: Blackwell. [ISBN: 9780631219361]

Myers-Scotton is probably best known for her work on grammatical and social aspects of code-switching. This book is designed primarily as a textbook for undergraduates and at times adopts an off-putting tone, but nonetheless is an excellent, straightforward overview of bilingualism and a good starting point in attempting to understand her complex (and not uncontroversial) model of code-switching.

Thomason, Sarah G. 2001. Language contact: An introduction. Edinburgh: Edinburgh Univ. Press. [ISBN: 9780748607198] 
Pitched at a relatively low level, but hugely informative and readable.

Thomason, Sarah G., and Terrence Kaufman. 1988. Language contact, creolization, and genetic linguistics. Berkeley: Univ. of California Press.[ISBN: 9780520912793]

An influential book that links modern research into language contact with work on historical linguistic situations. Cautiously discusses models and illustrates these with a wide range of linguistic situations. Demonstrates the tensions between contact linguistics and Indo-European linguistics.

\section{REGIONAL STUDIES}

The linguistic diversity of the Roman world means that every region presents a unique linguistic landscape and complex patterns of societal and individual bi- and multilingualism. This section presents useful items of bibliography for each of the following regions: *Rome and Italy*, *Sicily*, the *Iberian Peninsula*, *Gaul*, *Britain*, the *Germanies and Eastern Europe*, *Greece and Asia Minor*, *Egypt*, *North Africa*, and the *Near East*. Work on non-Latin and Greek languages in many areas has a long history, but this has often been in departments other than Classics departments (e.g., Germanic or Celtic studies). Coordinated work to understand bi- and multilingualism is still in its early phases (e.g., for Britain, Gaul, the Germanies, and Eastern Europe). Egypt might act as a model for multilingual investigations, since work on this region has a long history and has employed sophisticated linguistic approaches.

\section{Rome and Italy}

Rome and Italy present a diverse linguistic environment with a mix of Indo-European (e.g., Latin, Oscan, and Umbrian) and non-Indo-European languages (e.g., Etruscan). Work on these languages and their interactions has a long history (see, e.g., Homeyer 1957 for a general survey and references to earlier work) and is now entering a new phase of sophistication aided by the important publication, Crawford, et al. 2011. Penney 1988, Clackson and Horrocks 2007, and Benelli 2001 are useful introductory texts. Hadas-Lebel 2004 is key on Etruscan-Latin bilingualism, Leiwo 1994 is a good preliminary survey of a specific town, and Willi 2009 treats some issues in linguistic research using evidence from Faliscan, Umbrian, and Oscan.

Benelli, Enrico. 2001. Romanization of Italy through the epigraphic record. In Italy and the

West: Comparative issues in romanization. Edited by Simon J. Keay and Nicola Terrenato, 7-16. Oxford: Oxbow. [ISBN: 9781842170427]

A short introduction to the changes in the epigraphic record in the transition period in preRoman and Roman Italy. Emphasizes the regional differences in language and epigraphic culture. Useful bibliography.

Clackson, James, and Geoffrey C. Horrocks. 2007. The Blackwell history of the Latin language. Malden, MA, and Oxford: Wiley-Blackwell.

A handy survey of the history of the Latin language. An ideal starting point for all levels of interest and expertise (glossary provided). Bi- and multilingualism raised throughout, e.g., in discussions of the multilingual complexity of early Italy (chapter 2), the Greek influence on the road to standardization (chapter 5), the encounter of elite Latin with Greek (chapter 6), and the spread of sub-elite Latin through the Empire (chapter 7). Helpful select bibliography.

Crawford, Michael H., William Broadhead, and James Clackson, et al. 2011. Imagines italicae. 3 vols. London: Institute of Classical Studies. [ISBN: 9781905670307] Three volumes of inscriptions from ancient Italy, excluding those in Latin, Greek, Etruscan, Messapic, and Faliscan. Autopsy has been attempted, and, as far as possible, the texts are presented with references, an image, object information, date, last known location and 
autopsy, archaeological context and history, epigraphical account, text and apparatus, translation, and bibliography. An invaluable resource for studying the linguistic complexity of Italy, though Crawford is contemptuous about the value of sociolinguistic research (Vol. 1, p. 3).

Hadas-Lebel, Jean. 2004. Le bilinguisme étrusco-latin: Contribution à l'étude de la romanisation de l'Étrurie. Louvain, Belgium: Peeters. [ISBN: 9789042915138] Essential reading for anyone interested in Etruscan-Latin bilingualism. After a general introduction, Part 1 focuses on literary testimony; Parts 2 and 3, much longer, focus on epigraphy. Part 2 has a lengthy discussion of onomastic and morphological borrowings; Part 3, discussion of inscriptions displaying bilingual phenomena and bi-version bilingual inscriptions.

Homeyer, Helen. 1957. Some observations on bilingualism and language shift in Italy from the sixth to the third century B.C. Word 13:415-440.

An interesting, though now dated, survey of bilingualism in early Italy, describing evidence that can be marshaled and a range of extralinguistic influences (geographical conditions, political influences, commerce, rural areas, social status, and occupational groups).

Leiwo, Martti. 1994. Neapolitana: A study of population and language in Graeco-Roman Naples. Helsinki: Societas Scientarium Fennica. [ISBN: 9789516532724]

A book covering the historical background, cultural life under the Empire, and the epigraphic speech community of Graeco-Roman Naples. The discussion of inscriptions, naming practices, and the onomasticon are useful but outdated since the publication of Elena Miranda's two-volume corpus of Greek inscriptions, Iscrizioni greche d'Italia, Napoli (Rome: Casa Editrice Quasar, 1990-1995). More complex sociolinguistic work still remains to be undertaken.

Penney, John H. W. 1988. The languages of Italy. In The Cambridge ancient history. Vol. 4. Edited by John Boardman, Nicholas G. L. Hammond, David M. Lewis, and Martin Ostwald, 720-738. Cambridge, UK: Cambridge Univ. Press.

Remains the best place to start for a brief and clear survey of the linguistic diversity of ancient Italy.

Willi, Andreas. 2009. Opfer des Lateinischen: Zum sprachtod in Altitalien. Gymnasium 116:573-598.

First discusses the issue of identifying languages and dialects in the epigraphic remains (using the example of Faliscan), next tackles the problem of how to know when a language has died (using the example of Umbrian), and then considers the possible reasons for language death (using the example of Oscan).

\section{Sicily}

Sicily is an area that would benefit from more work specifically on bi- and multilingualism in the Roman period (many publications are focused on Greek and earlier periods). Tribulato 2012 is now the starting point. Korhonen 2011 and Prag 2002 offer interesting research on the epigraphy.

Korhonen, Kalle. 2011. Language and identity in the Roman colonies of Sicily. In Roman colonies in the first century of their foundation. Edited by Rebecca J. Sweetman, 7-31. Oxford: Oxbow. [ISBN: 9781842179741]

Useful overview, with some more detailed analysis, of choices made between Latin and Greek both in public epigraphy and funerary epitaphs of the Roman colonies in Sicily during the early imperial period. Presents evidence, both quantitative and qualitative, and offers conclusions about speech communities, linguistic and cultural identities, and relative prestige of different languages. Highlights geographical and chronological variation. 
Prag, Jonathan R. W. 2002. Epigraphy by numbers: Latin and the epigraphic culture in Sicily. In Becoming Roman, writing Latin? Edited by Alison E. Cooley, 15-31. Portsmouth, RI: Journal of Roman Archaeology. [ISBN: 9781887829489]

Within what he admits are preliminary assessments based on quantitative analysis of the lapidary inscriptions in Sicily from the 7th century BCE to the 7th century CE, Prag considers the distribution (geographical and chronological) of different languages in Sicily. Highlights important questions about the gaps between epigraphic culture and linguistic community. A useful springboard for further work.

Tribulato, Olga, ed. 2012. Language and linguistic contact in ancient Sicily. Cambridge, UK: Cambridge Univ. Press. [ISBN: 9781107029316]

Based on a conference in 2008, this informative volume contains a lengthy and wideranging chapter by the editor (pp. 1-45), followed by twelve chapters by leading experts split into three sections on non-classical languages, Greek, and Latin, respectively.

\section{Iberian Peninsula}

One of the most linguistically diverse areas of the Roman world with a complex pre- and early-period Roman written record (on some counts, twelve scripts, nine languages). A large amount of technical linguistic scholarship is produced annually. Listed here are some highlights of work specifically on bi- and multilingualism. Simkin 2012 and the first part of Ruiz Darasse and Luján 2011 are the best starting points. Untermann 1975- offers an extremely valuable collection of the "non-colonial" linguistic remains. Luján and García Alonso 2011 is a wide-ranging volume with some chapters of relevance for our theme. Beltrán Lloris 1999 and Panosa 1996 deal with specific parts of Spain in the early phases of Roman rule.

Beltrán Lloris, Francisco. 1999. Writing, language and society: Iberians, Celts and Romans in northeastern Spain in the second and first centuries BC. Bulletin of the Institute of Classical Studies 43:131-151.

Clear discussion of the linguistic and epigraphic situation in northeastern Spain in the early phase of Roman involvement.

Luján, Eugenio R., and Juan Luis García Alonso, eds. 2011. A Greek man in the Iberian street: Papers in linguistics and epigraphy in honour of Javier de Hoz. Innsbruck, Austria: Institut für Sprachen und Literaturen der Universität Innsbruck. [ISBN: 9783851247268] Multiple papers dedicated to de Hoz, a specialist on Iberian languages, several of which pertain to our theme. See, especially, the chapter on Greek-Latin code-switching by de Hoz García-Bellido and the chapter on linguistic contact between Celtiberian and Latin by Gorrochategui.

Panosa, María. 1996. Elementos sobre la fase de bilingüismo y latinización de la población ibérica. In La Hispania prerromana: Actas del VI Coloquio sobre Lenguas y Culturas Prerromanas de la Península Ibérica; Coimbra, 13-15 de octubre de 1994. Edited by Francisco Villar and José D’ Encarnação, 217-246. Salamanca, Spain: Ediciones Universidad de Salamanca. [ISBN: 9788474818307] [class:conference-paper] Historically informed discussion of evidence for bilingualism and Latinization amongst the Iberian population.

Ruiz Darasse, Coline, and Eugenio R. Luján, eds. 2011. Contacts linguistiques dans l'Occident méditerranéen antique. Madrid: Casa de Velázquez. [ISBN: 9788496820616] Part 1 of this volume based on a conference in 2009 is devoted to the Iberian peninsula. Beltrán Lloris and Estarán Tolosa discuss bilingualism and types of bilingual text (pp. 925), de Hoz discusses the role of Iberian as a lingua franca (pp. 27-64), Gorrochategui analyzes linguistic and epigraphic contact in the Vaso-Aquitanian zone (pp. 65-87), and 
finally Velaza Frías tackles conceptual and methodological questions concerning linguistic contact in pre-Roman and Roman Hispania (pp. 89-100).

Simkin, Oliver. 2012. Language contact in the pre-Roman and Roman Iberian peninsula. In Multilingualism in the Graeco-Roman worlds. Edited by Alex Mullen and Patrick James, 77-105. Cambridge, UK: Cambridge Univ. Press. [ISBN: 9781107013865]

A very good English-language starting point to try to make sense of a complex scholarship written largely in Romance languages. Highlights what we can and cannot know about language contact in the Iberian peninsula.

Untermann, Jürgen, ed. 1975-. Monumenta linguarum Hispanicarum. Wiesbaden, Germany: Ludwig Reichert Verlag. [ISBN: 9783920153537]

An impressive collection from a renowned expert that has revolutionized the field. Volume 1 in two parts concerns the coin legends; Volume 2, the inscriptions in Iberian script from the southwest of France (largely from Ensérune); Volume 3 in two parts, the Iberian inscriptions from Spain; Volume 4, the Tartessian, Celtiberian, and Lusitanian inscriptions; and Volume 5, a dictionary of Celtiberian by Dagmar Wodtko.

\section{Gaul}

The main non-Latin or Greek languages in Gaul belong to the Celtic language family. Iberian and Aquitanian were also spoken in the southwestern France. Unfortunately, Celtic and Classical linguistic studies have traditionally been relatively isolated from one another. Meid 1983 is a commonly cited article discussing bilingual texts. The only book-length treatment of bi- and multilingualism in Gaul is Mullen 2013b, which concentrates on Southern Gaul. Untermann 1992 is a summary of the linguistic landscape of the Hérault. The graffiti of La Graufesenque are particularly important bilingual texts, these are discussed by Adams 2003 (pp. 687-724, cited under *General Overviews*), Marichal 1988, and Mullen 2013a. For a basic introduction to the Gaulish language with information about loanwords in Latin and French, see Lambert 2003. Whatmough 1970 is a problematic volume but still regularly cited. Blom 2009 provides an important reminder of the range of linguistic varieties of Gaul and the problems of their pre-modern labels.

Blom, Alderik H. 2009. Lingua gallica, lingua celtica: Gaulish, Gallo-Latin, or GalloRomance? Keltische Forschungen 4:7-54.

A detailed discussion of the testimonia for, and meanings of, the adjectives gallica(na), celtica, and associated adverbs used to refer to language in Roman and medieval sources. Concludes that the terms cannot be uncritically translated as "Gaulish" and "Celtic" (and may mean Gallic Latin, Gallo-Romance, a specific style of speech, etc.) and a full account must include the precise context, genre, date, and provenance of the material in question.

Lambert, Pierre-Yves. 2003. La langue gauloise. 2d ed. Paris: Errance. [ISBN: 9782877722247]

The second edition of this important book on Gaulish contains a linguistic analysis of the language, discussion of epigraphic evidence, and a chapter on Gaulish words in French. Straightforwardly written and nicely illustrated.

Marichal, Robert. 1988. Les graffites de La Graufesenque. Paris: Presses du CNRS. [ISBN: 9782222038641]

A superb illustrated presentation of the Latin, Gaulish, and bilingual graffiti (largely firing lists) from La Graufesenque by a leading paleographer. Lengthy discussion of the scripts and language.

Meid, Wolfgang. 1983. Gallisch oder Lateinisch? Soziolinguistische und andere Bemerkungen zu populären gallo-lateinischen Inschriften. In Aufstieg und Niedergang der römischen Welt II.29. Edited by Hildegard Temporini and Wolfgang Haase, 1019-1044. Berlin: Walter de Gruyter. [ISBN: 9783110103762] 
An often-cited, though now dated, overview of bilingual texts from Gaul.

Mullen, Alex. 2013a. The language of the potteries: Communication in the production and trade of Gallo-Roman terra sigillata. In Seeing red: New economic and social perspectives on terra sigillata. Edited by Michael G. Fulford and Emma Durham, 97-110. London: Institute of Classical Studies. [ISBN: 9781905670475]

A discussion of the nature of the language mixture in the graffiti from La Graufesenque (see Marichal 1988), demonstrating that we may have to be more cautious than Adams 2003 (cited under *General Overviews*) about recovering individual bilingualism and may need to add Greek to the Latin and Gaulish in the mix.

Mullen, Alex. 2013b. Southern Gaul and the Mediterranean: Multilingualism and multiple identities in the Iron Age and Roman periods. Cambridge, UK: Cambridge Univ. Press. [ISBN: 9781107020597]

A new assessment of the linguistic and cultural interactions of Southern Gaul in the Iron Age and Roman periods combining sociolinguistic, historical, and archaeological material and approaches.

Untermann, Jürgen. 1992. Quelle langue parlait-on dans l'Hérault pendant l'Antiquité? Revue archéologique de Narbonnaise 25:19-27.

A concise starting point for investigating the linguistic situation of southwestern Gaul.

Whatmough, Joshua. 1970. The dialects of Ancient Gaul: Prolegomena and records of the dialects. Cambridge, MA: Harvard Univ. Press.

A huge and unwieldy book that assembles Gaulish material from a range of sources. The title is misleading because Whatmough simply organizes the evidence regionally, rather than seriously attempting any dialectology. Full of errors and out of date, but still used as a reference work as it contains an introduction and is sometimes useful for mining examples. For the Gaulish inscriptions, the several volumes of the Recueil des Inscriptions Gauloises (Paris: Presses du CNRS, 1984-) should be consulted.

\section{Britain}

The classic treatment of language in early Britain is Jackson 1953 and though now out of date and questioned in many respects (Gratwick 1982), nothing has yet completely replaced it. For overviews of the material and issues at stake, see Evans 1983 and Russell 2012. For recent work on the material found in Britain, see Adams 1992 and Mullen 2007b on texts from Bath, Adams 2003 on Vindolanda tablets, and Mullen 2007a on Romano-British names.

Adams, James N. 1992. British Latin: The text, interpretation and language of the Bath curse tablets. Britannia 23:1-26.

A brilliant discussion of the interesting linguistic features of the Bath curse tablets, some of which betray evidence of British Celtic. See also Mullen 2007b.

Adams, James N. 2003. The new Vindolanda writing-tablets. Classical Quarterly 53:530 575.

The Vindolanda tablets, found in northeastern Britain, bear witness, among other things, to Latin in contact with Germanic and Celtic languages (languages of the recruits [Celtic and/or Germanic and Latin] and locals [Celtic and Latin]). This article is the second clear and detailed discussion of the interesting linguistic features of the tablets; the earlier material is discussed in Adams 2003 (s.v. "Vindolanda," cited under *General Overviews*)

Evans, David Ellis. 1983. Language contact in pre-Roman and Roman Britain. In Aufstieg und Niedergang der römischen Welt II.29. Edited by Hildegard Temporini and Wolfgang Haase, 949-987. Berlin: Walter de Gruyter. [ISBN: 9783110103762] An excellent survey of what we know, and what we do not know, about linguistic contacts in pre-Roman and Roman Britain from a renowned Celticist. 
Gratwick, Adrian S. 1982. Latinitas Britannica: Was British Latin Archaic? In Latin and the vernacular languages in early medieval Britain. Edited by Nicholas P. Brooks, 1-79. Leicester, UK: Leicester Univ. Press. [ISBN: 9780718512095]

An at times shockingly vitriolic attack on Jackson 1953, but which makes important points and has informed subsequent research. Gratwick is correct in attacking Jackson's construction of an archaic Latinitas Britannica, but not always for the right reasons.

Jackson, Kenneth H. 1953. Language and history in Early Britain: A chronological survey of the Brittonic languages, first to twelfth century A.D. Edinburgh: Edinburgh Univ. Press. The most influential book on language in early Britain, still revered by Celticists (though questioned) and unfairly overlooked by Classicists. Classicists ignore this at their peril because, although it is now over sixty years old, it contains much information on late preRoman Iron Age and Roman Britain, and nothing has come close to replacing it.

Mullen, Alex. 2007a. Linguistic evidence for Romanization: Continuity and change in Romano-British onomastics. Britannia 38:35-61.

A discussion of what can be done with onomastic evidence and what it might tell us about cultural interaction, bilingualism, etc. Designed to be read with the online database of Celtic personal names, ${ }^{*}$ CPNRB[http://www.asnc.cam.ac.uk/personalnames/]*, compiled and updated annually by Alex Mullen and Paul Russell following the publication of new inscriptions from Roman Britain in the journal Britannia.

Mullen, Alex. 2007b. Evidence for written Celtic from Roman Britain: A linguistic analysis of Tabellae Sulis 14 and 18. Studia Celtica 41:31-45.

A technical discussion of two tablets from the Bath collection which may be written in Celtic, either British or Continental.

Russell, Paul. 2012. An habes linguam Latinam? Non tam bene sapio: Views of multilingualism from the early medieval West. In Multilingualism in the Graeco-Roman worlds. Edited by Alex Mullen and Patrick James, 193-224. Cambridge, UK: Cambridge Univ. Press. [ISBN: 9781107013865]

An incisive survey of multilingualism in the British Isles and, briefly, Gaul in the early medieval period. Contains a valuable final section on Roman Britain.

\section{Germanies and Eastern Europe}

The Germanies and Eastern Europe are ripe for more investigation into bi- and multilingualism; Blänsdorf 2010, Destephen 2011, and Eck 2004 alert us to material that ought to be exploited further. Plenty of work has been done recently on the onomastic material, e.g., Falileyev 2013, Kakoschke 2006-2008, and Kakoschke 2009, but little of significance concerning language contact more broadly. Schrijver 2014 is one of a few recent items to treat the Roman period and the effects of bilingualism.

Blänsdorf, Jurgen. 2010. The defixiones from the sanctuary of Isis and Mater Magna in Mainz. In Magical practice in the Latin West: Papers from the International Conference held at the University of Zaragoza, 30 Sept.-1 Oct. 2005. Edited by Richard L. Gordon and Francisco Marco Simón, 141-189. Leiden, The Netherlands, and Boston: Brill. [ISBN: 9789004179042] [class:conference-paper]

Not specifically on bilingualism, but of relevance. Discussion of the Latin defixiones relatively recently found in Mainz. The material is important for our understanding of Latinization, regional Latin, and cultural interactions, though this article does not fully exploit the material.

Destephen, Sylvain. 2011. La coexistence du grec et du latin en Illyricum (Ier-VIe siècle). In Contacts linguistiques dans l'Occident méditerranéen antique. Edited by Coline Ruiz Darasse and Eugenio R. Luján, 129-144. Madrid: Casa de Velázquez. [ISBN: 9788496820616] 
Brief discussion, illustrated with distribution maps, of the coexistence of Greek and Latin in Illyricum.

Eck, Werner. 2004. Lateinisch, Griechisch, Germanisch . . .? Wie sprach Rom mit seinen Untertanen? In Roman rule and civic life: Local and regional perspectives: Proceedings of the fourth workshop of the international network impact of Empire (Roman Empire, c. 200 B.C.-A.D. 476), Leiden, June 25-28, 2003. Edited by Luuk de Ligt, Emily A. Hemelrijk, and Henk W. Singor, 3-19. Amsterdam: J. C. Gieben. [ISBN: 9789050634182] [class:conference-paper]

Eck reminds us of the importance of thinking about Rome's relationship with non-Latin or Greek speakers under its sway. Relevant for the whole empire, but several examples offered relate to the Germanies, where the large numbers of military men will have had a considerable impact.

Falileyev, Alexander. 2013. The Celtic Balkans. Aberystwyth, UK: CMCS. [ISBN: 9780955718243]

The first full study of the Celtic place and personal names of Albania, Bulgaria, Greece, Kosovo, Macedonia, Montenegro, Serbia, and the European part of Turkey.

Kakoschke, Andreas. 2006-2008. Die Personennamen in den zwei germanischen Provinzen: Ein Katalog. 3 vols. Rahden, Germany: Leidorf.

A catalogue of the personal names of Germania superior and inferior.

Kakoschke, Andreas. 2009. Die Personennamen in der römischen Provinz Rätien.

Hildesheim, Germany, and New York: Olms-Weidmann. [ISBN: 9783487139173]

A catalogue of the personal names of Raetia.

Schrijver, Peter. 2014. Language contact and the origins of the Germanic languages. London and New York: Routledge. [ISBN: 9780415355483]

A historical linguistic approach to the origins of English, German, Dutch, and the Germanic language family. Starts in the 1st millennium BCE and deals with developments in the Roman period.

\section{Greece and Asia Minor}

Key book-length treatments are Bagnall 2011 and Horrocks 2010 (both ranging beyond Greece and Asia Minor) and Kearsley and Evans 2001 (restricted to Imperial Asia). Brixhe 2002 focuses on Greek and Phrygian under Rome. Other important work has picked Delos as a center of interest; see Adams 2003 and Hasenohr 2008.

Adams, James N. 2003. Bilingualism and the Latin language. Cambridge, UK: Cambridge Univ. Press. [ISBN: 9780521817714]

Excellent overview of the complex sociolinguistic situation on Delos and of the various motivations for language use there (pp. 642-686). Offers useful comparisons with linguistic evidence from other contexts to highlight the distinctive character of bilingualism on the island and discusses important questions about identity and self-presentation of Italians.

Bagnall, Roger S. 2011. Everyday writing in the Graeco-Roman East. Berkeley and London: Univ. of California Press. [ISBN: 9780520267022]

Useful work focusing on evidence that is rarely collated. Through six chapters, each examining a different case study or corpus, Bagnall considers a wide range of evidence in a number of languages. Emphasizes the importance of confronting and understanding silences in the evidence and concludes that writing was a much more widespread social phenomenon than is sometimes acknowledged. Also relevant for *Egypt*.

Brixhe, Claude. 2002. Interactions between Greek and Phrygian under the Roman Empire. In Bilingualism in ancient society: Language contact and the written text. Edited by James $\mathrm{N}$. Adams, Mark Janse, and Simon Swain, 246-266. Oxford: Oxford Univ. Press. [ISBN: 9780199245062] 
Analysis of interaction between Greek and Phrygian as evidenced by neo-Phrygian inscriptions of the 3rd century CE. Combination of detailed linguistic analysis and overview of historical context.

Hasenohr, Claire. 2008. Le bilinguisme dans les inscriptions des magistri de Délos. In Bilinguisme gréco-latin et épigraphie: Actes du colloque organisé à l'Université LumièreLyon 2 . . les 17, 18 et 19 mai 2004. Edited by Frédérique Biville, Jean-Claude Decourt, and Georges Rougemont, 55-70. Lyon, France: Maison de l'Orient Méditerranéen. [ISBN: 9782356680006] [class:conference-paper]

Detailed study of about thirty Greek, Latin, and bilingual inscriptions by magistri on Delos. Challenges and nuances some of Adams's interpretations in his chapter on Delos (Adams 2003 pp. 642-686) and provides an engaging analysis of the relationships between the two languages, using this to suggest conclusions about the purpose and readership of the inscriptions.

Horrocks, Geoffrey C. 2010. Greek: A history of the language and its speakers. $2 \mathrm{~d}$ ed. Chichester, UK, and Malden, MA: Wiley-Blackwell. [ISBN: 9781405134156] History of Greek from the earliest dialects to those in the early 21 st century, charting major linguistic developments and social context of the speakers. Particularly useful for our purpose is chapter 5, "Greek in the Roman Empire," discussing Greek's fate under Roman rule. Linguistic consequences of contact between Greek and Latin are summarized (pp. 126-133).

Kearsley, Rosalinde, and Trevor V. Evans. 2001. Greeks and Romans in imperial Asia: Mixed language inscriptions and linguistic evidence for cultural interaction until the end of AD III. Bonn, Germany: R. Habelt. [ISBN: 9783774930322]

Primarily a thematic catalogue of non-official Greek-Latin bilingual inscriptions from the province of Asia from the Augustan principate to the 3rd century CE. Commentary has a sociohistorical rather than purely linguistic focus. Useful discursive overview of inscriptions and the light they shed on cultural and linguistic interaction in Asia. Helpful indexes of Greek words, Latin personal names, and some orthographic features. Appendix of loanwords.

\section{Egypt}

Egypt is a region for which picking a handful of citations is extremely difficult; the depth and sophistication of research into bi- and multilingualism remains unrivaled. Starting points might be the overviews by Depauw 2012, Fewster 2002, and Fournet 2009. Perhaps the most comprehensive overview can be found in Adams 2003 (cited under *General Overviews*), especially in the lengthy chapter 5 , but also passim. The citations listed here demonstrate the breadth of the field: Adams 1977 on a bilingual archive; Dickey 2012 and Dickey 2015 on bilingual teaching manuals, Evans and Obbink 2010 on a range of linguistic subjects, Marganne and Rochette 2013 on the use of two languages and scripts in the Latin papyri, Papaconstantinou 2010 on multilingual experience, Salomon 1991 on Indian traders, and Vierros 2012 on scribal practices.

Adams, James N. 1977. The Vulgar Latin of the letters of Claudius Terentianus. Manchester, UK: Manchester Univ. Press. [ISBN: 9780719012891]

Although now slightly outdated in places given Adams's own prolific subsequent research, this excellent survey of the language of the Latin letters of the bilingual archive of Claudius Terentianus remains a key reference text. Covers phonology, morphology, syntax, word order, and vocabulary.

Depauw, Mark. 2012. Language use, literacy, and bilingualism. In The Oxford handbook of Roman Egypt. Edited by Christina Riggs, 493-506. Oxford: Oxford Univ. Press. [ISBN: 9780199571451] 
A helpful overview of linguistic and cultural interaction and language attitudes in Roman Egypt. Focuses especially on the interactions and fate of Greek and Egyptian languages in their various forms; argues that, although the Romans did not impose Latin, Roman attitudes did precipitate the decline of local Demotic. Useful suggestions for further reading.

Dickey, Eleanor. 2012. The colloquia of the Hermeneumata Pseudodositheana. Vol. 1, Colloqui Monacensia-Einsidlensia, Leidense-Stephani, and Stephani. Cambridge, UK: Cambridge Univ. Press. [ISBN: 9781107020108]

First volume of a two-volume set (see Dickey 2015) that constitutes a phenomenal new edition, translation, and commentary of these bilingual teaching manuals. Volume 1 contains a clear introduction to language learning in antiquity.

Dickey, Eleanor. 2015. The colloquia of the Hermeneumata Pseudodositheana. Vol. 2, Colloquium Harleianum, colloquium Montepessulanum, colloquium Celtis, and fragments. Cambridge, UK: Cambridge Univ. Press. [ISBN: 9781107065390]

Second volume of a two-volume set (see Dickey 2012) that constitutes a phenomenal new edition, translation, and commentary of these bilingual teaching manuals.

Evans, Trevor V., and Dirk D. Obbink, eds. 2010. The language of the papyri. Oxford: Oxford Univ. Press. [ISBN: 9780199237081]

A volume based on a conference in 2006. An introduction followed by sixteen chapters divided into two main subjects: linguistic change and diversity, and language contact.

Fewster, P. 2002. Bilingualism in Roman Egypt. In Bilingualism in ancient society: Language contact and the written text. Edited by James N. Adams, Mark Janse, and Simon Swain, 220-245. Oxford: Oxford Univ. Press. [ISBN: 9780199245062]

Excellent chapter offering an overview of types of Greek-Egyptian bilingualism in Roman Egypt. Applies Charlotte Hoffman's concept of "bilingual profiles" as a way to assess language competencies and attitudes. Highlights the problems that the evidence leaves open for the historian.

Fournet, Jean-Luc. 2009. The multilingual environment of late antique Egypt: Greek, Latin, Coptic, and Persian documentation. In The Oxford handbook of papyrology. Edited by Roger S. Bagnall, 418-451. Oxford: Oxford Univ. Press. [ISBN: 9780195178388] An engaging overview of the evidence for linguistic interaction of Latin, Coptic, and Pehlevi with Greek in Egypt between the 4th and 7th centuries CE. Considers the broader historical context of the multilingual situation and how it changed over time.

Marganne, Marie-Hélène, and Bruno Rochette, eds. 2013. Bilinguisme et digraphisme dans le monde gréco-romain: L'apport des papyrus latins; Actes de la table ronde internationale (Liège, 12-13 mai 2011). Liège, Belgium: Presses de l'Université de Liège. [ISBN: 9782875620224] [class: conference-proceeding]

Collection of papers presenting up-to-date perspectives on various aspects of bilingualism and digraphism in Latin papyri. Helpful introductory section including an overview by Rochette of the state of scholarship on bilingualism in the Latin papyri and two bibliographic chapters. Followed by some more narrowly focused papers, e.g., on accentuation and the Vergilian bilingual glossaries. Papers are in French, English, and Italian; English abstracts of all papers are included.

Papaconstantinou, Arietta, ed. 2010. The multilingual experience in Egypt from the Ptolemies to the Abbasids. Farnham, UK: Ashgate. [ISBN: 9780754665366]

Excellent, wide-ranging collection of papers that present various aspects of the rich and varied evidence for multilingualism in Egypt between the 3rd century BCE and the 8th century CE. Divided into two sections: Part 1 presents an overview of the evidence from different periods, whereas Part 2 examines some case studies in detail. Sociohistorical in focus but also includes technical linguistic analysis. 
Salomon, Richard. 1991. Epigraphic remains of Indian traders in Egypt. Journal of the American Oriental Society 111.4: 731-736.

Discussion of the fragmentary linguistic evidence for the presence of Indian traders in Roman Egypt, on both a temporary and a more permanent basis.

Vierros, Marja. 2012. Bilingual notaries in Hellenistic Egypt: A study of Greek as a second language. Collectanea hellenistica 5. Brussels: Koninklijke Vlaamse Academie van België voor Wetenschappen en Kunsten. [ISBN: 9789065691033]

Study of the Greek language and its variations in a corpus of 150 notarial contracts from Upper Egypt dating to between 174 and 88 BCE. Considers the nature of the notaries' bilingualism and language learning and the language attitudes and practices in their community. Part 1 examines the sociolinguistic context in which the notaries were writing; Part 2 offers a linguistic analysis of the Greek, including chapters on phonology, morphology, and syntax.

\section{North Africa}

Starting points for immersion in the linguistic entanglements of this area are Levi della Vida 1963, Millar 1968, and Wilson 2012. Important material can be found at Bu Njem; see Adams 1994 on the ostraca and Adams 1999 on two stone inscriptions.

Adams, James N. 1994. Latin and Punic in contact? The case of the Bu Njem Ostraca. Journal of Roman Studies 84:87-112.

A rigorous analysis of the evidence for language contact in the ostraca from $\mathrm{Bu} \mathrm{Njem}$. Adams, James N. 1999. The poets of Bu Njem: Language, culture and the centurionate. Journal of Roman Studies 89:109-134.

A detailed discussion of the language of two poems by centurions posted at $\mathrm{Bu} \mathrm{Njem}$ and their linguistic abilities.

Jongeling, Karel, and Robert Kerr. 2005. Late Punic epigraphy: An introduction to the study of Neo-Punic and Latino-Punic inscriptions. Tübingen, Germany: Mohr Siebeck. [ISBN: 9783161487286]

A useful slim volume. Opens with an introduction to the Neo-Punic and Latino-Punic inscriptions (Punic inscriptions postdating the Roman conquest in Neo-Punic and Latin script, respectively), which covers definitions, information about the survival of the language, orthographic conventions, and the nature of the texts. Followed by a presentation of more than one hundred inscriptions (text, translation, illustration, and remarks), glossaries, lists of inscriptions, bibliography, and Neo-Punic paleographic chart.

Levi della Vida, Georgio. 1963. Sulle iscrizioni "latino-libiche" della Tripolitania. Oriens Antiquus 2:65-94.

An important early discussion of Punic-Latin bilinguals from Tripolitania.

Millar, Fergus. 1968. Local cultures in the Roman Empire: Libyan, Punic and Latin in Roman Africa. Journal of Roman Studies 58:126-134.

Remains a clear and valuable starting point for thinking about linguistic interaction in Roman Africa. To be read with Wilson 2012.

Wilson, Andrew. 2012. Neo-Punic and Latin inscriptions in Roman North Africa: Function and display. In Multilingualism in the Graeco-Roman worlds. Edited by Alex Mullen and Patrick James, 265-316. Cambridge, UK: Cambridge Univ. Press. [ISBN: 9781107013865] An interdisciplinary approach to the neo-Punic and Latin inscriptions from Roman North Africa. Focus is on the function, display, and languages of the building inscriptions, but summaries of the linguistic and epigraphic situation more generally make this piece essential reading. 


\section{Near East}

The linguistic material for the Near East is extremely fertile, and several of the references included here note that further research is needed. The starting point for research should be Cotton, et al. 2009. Fergus Millar is a key specialist in this zone who has produced several excellent articles, including Millar 1998, Millar 2008, and Millar 1995, the latter of which exploits Palmyra as a particularly interesting trilingual epigraphic case study. Cotton 1999 focuses on material from the Judaean desert; MacAdam 1983, on southern Syria.

Cotton, Hannah M. 1999. The languages of the legal and administrative documents from the Judaean Desert. Zeitschrift für Papyrologie und Epigraphik 125:219-231.

A summary of Greek and Semitic legal documents, some collated elsewhere and others remaining unpublished, from Judaea and the province of Arabia. Discussion of the variety of languages involved and their different roles, both practical and symbolic.

Cotton, Hannah M., Robert G. Hoyland, Jonathan J. Price, and David J. Wasserstein, eds. 2009. From Hellenism to Islam: Cultural and linguistic change in the Roman Near East. Cambridge, UK: Cambridge Univ. Press. [ISBN: 9780521875813]

An excellent volume split into five parts: Latin in the Near East; social and legal institutions as reflected in the documentary evidence; the epigraphic language of religion; linguistic metamorphoses and continuity of cultures; Greek into Arabic. Important chapters for our topic include Millar's introduction (pp. 1-12), Eck on Latin in the Roman Near East (pp. 15-42), Isaac on Latin in the cities of the Roman Near East (pp. 43-72), and Belayche on the impact of Rome on Palestine (pp. 177-202).

MacAdam, Henry I. 1983. Epigraphy and village life in Southern Syria during the Roman and Early Byzantine periods. Berytus 31:103-115.

Preliminary survey, using Greek inscriptions, of organization of village life in Syria. Provides some evidence of Semitic interaction with Greek and of the limitations of Hellenization within the region. Highlights need for further research in this area.

Millar, Fergus. 1995. Latin in the Epigraphy of the Roman Near East. In Acta colloquii epigraphici Latini: Helsingiae 3.-6. Sept. 1991 habiti. Edited by Heikki Solin, Olli Salomies, and Uta-Maria Lierz, 403-419. Helsinki: Societas Scientiarum Fennica. [ISBN: 9789516532779] [class:conference-paper]

Discussion of the interplay among Latin, Greek, and Semitic languages in the Near East, focusing on the trilingual epigraphic evidence from Palmyra and outlining the scope for further work in this area.

Millar, Fergus. 1998. Ethnic identity in the Roman Near East, AD 325-450: Language, religion and culture. Mediterranean Archaeology 11:159-176.

A detailed discussion of the varied ethnicities within the Roman Near East in the 4th and 5 th centuries and of the role of languages in shaping and expressing these different identities.

Millar, Fergus. 2008. Community, religion and language in the Middle Euphrates region in late antiquity. Scripta Classica Israelica 27:67-93.

A detailed analysis of a wide range of linguistic and cultural evidence, rarely before collated, for ethnic and linguistic diversity in the mid-Euphrates zone. Millar questions how best to characterize this situation and highlights the difficulties of distinguishing between "indigenous" and "immigrant" groups.

\section{ATTITUDES TOWARD LANGUAGE AND LANGUAGE POLICY}

On language and identity, see the recent offerings by Adams 2003, Clackson 2015, Häussler 2008, Langslow 2012, and Rochette 2005; for an older and influential piece, which is now attacked, see MacMullen 1966. For language policy, Dubuisson 1982 and Rochette 2011 are valuable studies. For the use of interpreters, see Mairs 2012. For attitudes toward 
bilingualism, see Dubuisson 1982 on the meaning of the main terms, a subject that has received surprisingly little attention.

Adams, James N. 2003. "Romanitas" and the Latin language. Classical Quarterly n.s. 53.1: 184-205.

A wonderful article that could function as a useful summary of the cultural aspects of Adams 2003 (cited under *General Overviews*).

Clackson, James. 2015. Language and society in the Greek and Roman worlds. Cambridge, UK: Cambridge Univ. Press. [ISBN: 9780521192354]

This book, from the "key themes in Ancient History" series, presents a lively discussion of the importance of language for understanding the ancient world and considers the creation of standard languages (chapter 2) and language and identity (e.g. chapter 3 on bilingualism, chapter 4 on sociolinguistic variation, chapter 5 on gender and sexuality).

Dubuisson, Michel. 1982. Y a-t-il une politique linguistique romaine? Ktéma 7:187-216. An important statement on Roman language policy, which is still often cited; should be read with Rochette 2011.

Dubuisson, Michel. 1983. Recherches sur la terminologie antique. Revue de philologie, de littérature et d'histoire ancienne 58.2: 203-225.

A discussion that considers the use of the Greek and Roman terms related to bi- and multilingualism, especially $\delta$ '́ $\gamma \lambda \omega \sigma \sigma o \zeta$ and bilinguis.

Häussler, Ralph, ed. 2008. Romanisation et épigraphie: Etudes interdisciplinaires sur l'acculturation et l'identité dans l'Empire romain. Montagnac, France: Editions Monique Mergoil. [ISBN: 9782355180071]

A series of papers considering epigraphic evidence for identity in the Roman Empire. Sections on Italy, the Cottian Alps, Gaul, Iberia, the Germanies, Britannia, and Phrygia containing papers of varying quality and length.

Langslow, David. 2012. Integration, identity, and language shift: Strengths and weaknesses of the "linguistic" evidence. In Processes of integration and identity formation in the Roman Republic. Edited by Saskia T. Roselaar, 289-309. Leiden, The Netherlands, and Boston: Brill. [ISBN: 9789004229112]

A short discussion of some of the theoretical issues with approaching linguistic (largely epigraphic) evidence from the ancient world. Suggests modeling and interdisciplinarity are the way forward (referring to the thesis now published as Mullen 2013b (cited under *Regional Studies: Gaul*)).

MacMullen, Ramsay. 1966. Provincial languages in the Roman Empire. American Journal of Philology 87:1-17.

Frequently cited argument that some provincial languages underwent a resurgence in the late 2nd century, reaching a peak by the end of the 4th century. Strongly rebutted, e.g., by Clackson in Mullen and James 2012 (cited under *General Overviews*) and Millar 1998 (cited under *Regional Studies: Near East*).

Mairs, Rachel. 2012. "Interpreting" at Vindolanda: Commercial and linguistic mediation in the Roman army. Britannia 43:17-28.

One of several short articles by Mairs alerting us to the importance of, and need for, linguistic mediation in the ancient world in a range of domains. Here the author's focus is on evidence for interpreters in the Roman army. She notes that we need to be aware that commercial mediation, rather than linguistic mediation, may be at stake.

Rochette, Bruno. 2005. La langue comme facteur d'intégration ou d'exclusion: L'Athènes de Périclès et la Rome de Cicéron. In Serta antiqua et mediaevalia VII: Il cittadino, lo straniero, il barbaro, fra integrazione ed emarginazione nell'antichità; Atti del I Incontro Internazionale di Storia Antica, Genova 22-24 maggio 2003. Edited by Maria Gabriella 
Angeli-Bertinelli and Angela Donati, 3-20. Rome: Giorgio Bretschneider. [ISBN: 9788876892332] [class:conference-paper]

An enjoyable and informative comparative discussion of the relationship between language and identity in 5th-century Athens and Late Republican Rome and the way in which language could work as both an integrative and exclusionary force.

Rochette, Bruno. 2011. Language policies in the Roman Republic and Empire. In $A$ companion to the Latin language. Edited by James Clackson, 549-563. Malden, MA, and Oxford: Wiley-Blackwell. [ISBN: 9781405186056]

A clear and authoritative overview of the evidence for linguistic attitudes and nebulous linguistic policies rather than an official language policy in the Roman Republic and Empire.

\section{GREEK AND OTHER LANGUAGES IN LATIN LITERATURE}

This is obviously a vast subject, for which a representative sample of linguistic approaches is offered. The majority of the output concerns the use of Greek in Latin literature; see, e.g., important offerings within large volumes such as Adams and Mayer 1999 and Garcea, et al. 2013 or monographs devoted to the theme such as Cavalca 2001 and Hutchinson 2013, also see de Melo 2012 for Punic. A recurrent theme within this subject is code-switching. The best overviews of code-switching are Jocelyn 1999 and Rochette 2007. Perhaps the most influential work has been done by Adams 2003 (pp. 308-347, cited under *General Overviews*) and Swain 2002 on code-switching in works by Cicero; see also Swain 2004 for code-switching in works by 2nd-century authors and Wenskus 1998 on Latin prose, mainly Cicero.

Adams, James N., and Roland G. Mayer, eds. 1999. Aspects of the language of Latin poetry. Oxford: Oxford Univ. Press for the British Academy. [ISBN: 9780197261781]

An important volume, with useful contributions relevant to our subject, e.g., by Mayer on the use of Greek syntax in Latin poetry and its reception by ancient and modern commentators and by Sedley on the use and avoidance of Greek by Lucretius.

Cavalca, Maria Grazia. 2001. I grecismi nel Satyricon di Petronio. Bologna, Italy: Pàtron. [ISBN: 9788855525978]

This collection and analysis of 186 Grecisms arranged alphabetically is a useful starting point for further literary and linguistic study. Covers the whole text, not just the Cena Trimalchionis.

de Melo, Wolfgang, ed. and transl. 2012. Plautus: IV, The little Carthaginian; Pseudolus; The rope. Cambridge, MA, and London: Harvard Univ. Press.

De Melo leaves the Punic passages of the Poenulus untranslated. He opines, contra Adrian Gratwick, that since most of the audience would not have understood, a Latin translation followed. A discussion of the Punic passages (pp. 173-222) includes information on the relationship of Punic to other languages, script, morphology and syntax, metrical structure, discussion of the texts, and bibliography.

Garcea, Alessandro, Marie-Karine Lhommé, and Daniel Vallat, eds. 2013. Polyphonia Romana: Hommages à Frédérique Biville. 2 vols. Hildesheim, Germany, and New York: Georg Olms Verlag. [ISBN: 9783487150871]

A huge double volume in honor of Biville. Volume 1 has a section on bilingualism and literature, which contains several papers of relevance to our theme: Callebat on Greek in Vitruvius, Guillaumin on the use of Greek in Martianus Capella, Joffre on Greeks speaking Latin in Ovid's Metamorphoses, Maltby on Greek in Servius's Commentaries on Vergil, and Rochette on Greek in Pliny the Younger.

Hutchinson, Gregory O. 2013. Greek to Latin: Frameworks and contexts for intertextuality. Oxford: Oxford Univ. Press. [ISBN: 9780199670703] 
A huge and dense book packed with interesting and relevant material.

Jocelyn, Harry D. 1999. Code-switching in the comoedia palliata. In Rezeption und identität:

Die kulturelle Auseinandersetzung Roms mit Greichenland als europäisches Paradigma.

Edited by Gregor Vogt-Spira and Bettina Rommel, 169-195. Stuttgart: F. Steiner.

Much more than a chapter on the comoedia palliata, this is a rich survey of examples of, and attitudes toward, Greek-Latin code-switching in the Roman literature of the Republic and early Empire and a great place to mine facts and bibliography.

Rochette, Bruno. 2007. Code-switching chez Ausone. In Etre romain: Hommages in memoriam Charles Marie Ternes. Edited by Robert Bedon and Michel Polfer, 175-195.

Remshalden, Germany: B. A. Greiner. [ISBN: 9783935383974]

Much more than a discussion of the motivations and identification of Ausonius's codeswitching, also discusses the practice of code-switching in Roman literature more generally and the linguistic situation in 4th-century Gaul.

Swain, Simon. 2002. Bilingualism in Cicero? The evidence of code-switching. In Bilingualism in ancient society: Language contact and the written text. Edited by James $\mathrm{N}$. Adams, Mark Janse, and Simon Swain, 128-167. Oxford: Oxford Univ. Press. [ISBN: 9780199245062]

An excellent chapter which should be read in conjunction with Adams 2003 (pp. 308-347, cited under *General Overviews*).

Swain, Simon. 2004. Bilingualism and biculturalism in Antonine Rome: Apuleius, Fronto, and Gellius. In The worlds of Aulus Gellius. Edited by Leofranc Holford-Strevens and Amiel Vardi, 3-40. Oxford: Oxford Univ. Press. [ISBN: 9780199264827]

Erudite discussion of the use of Greek by three key Roman authors in the 2nd century CE.

Wenskus, Otta. 1998. Emblematischer Codewechsel und Verwandtes in der lateinischen

Prosa: Zwischen Nähesprache und Distanzsprache. Innsbruck, Austria: Institut für Sprachwissenschaft der Universität Innsbruck. [ISBN: 9783851246728]

An often-cited short work by an expert in code-switching in Latin literature. Inspired by the modern sociolinguist Shana Poplack and devoted largely to examples from Cicero.

\section{TRANSLATION LITERATURE}

Translation literature has generated a large amount of scholarship; this selection highlights the bilingual dimension. Brock 1979 is the locus classicus; work such as that by Burton 2000 and Langslow 2012 tests the modes of translation through detailed linguistic analysis. Bortolussi, et al. 2009; Kittel, et al. 2007; and Rochette 1997 take a more cultural and historical approach.

Bortolussi, Bernard, Madeleine Keller, Sophie Minon, and Lyliane Sznajder, eds. 2009. Traduire, transposer, transmettre: Dans l'Antiquité gréco-romaine; Textes, images et monuments de l'Antiquité au haut Moyen âge 9. Paris: Éditions A. et J. Picard. [ISBN: 9782708408388] [class:conference-proceedings]

The proceedings of a conference held in 2007, fifteen chapters plus an introduction and conclusion, split into three sections. Most of the papers have a literary focus, though epigraphic evidence features in the second section. The first section is particularly useful for those interested in translation literature.

Brock, Sebastian P. 1979. Aspects of translation technique in antiquity. Greek, Roman and Byzantine Studies 20:69-87.

A clear and often-cited exposition that highlights the distinction between free translation (sensus de sensu) and literal translation (verbum e verbo) and then discusses the factors motivating the choice to translate literally and the techniques of the translators, using examples largely from Biblical contexts. 
Burton, Philip H. 2000. The Old Latin Gospels: A study of their texts and language. Oxford: Oxford Univ. Press. [ISBN: 9780198269885]

Essential reading covering textual history, translation techniques, and the Old Latin Gospels as linguistic documents. In a meticulous analysis of lexis, morphology, and syntax, Burton challenges the view that the translators had poor knowledge of Latin and the classification of the translation as "literal" and an example of "Vulgar Latin."

Kittel, Harald, Juliane House, and Brigitte Schultze, eds. 2007. Übersetzung: Ein internationales Handbuch zur Übersetzungsforschung. Vol. 2. Berlin: Walter de Gruyter. Chapter 17 of this encyclopedia on translation treats the ancient world and offers entries by Swain on translation and education in ancient Rome, Powell on Cicero's translation strategies, Harrison on Vergil and imitatio, Holford-Strevens on Aulus-Gellius, Vardi on the reception of translations at Rome, Stevenson on translation and the spread of Greek and Latin alphabets in Late Antiquity, and Lamberton on translation in Late Antiquity.

Langslow, David. 2012. Typologies of translation techniques in Greek and Latin: Latin

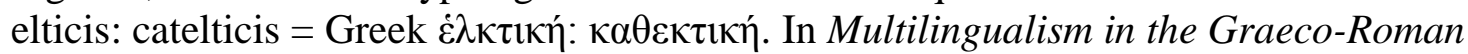
worlds. Edited by Alex Mullen and Patrick James, 141-171. Cambridge, UK: Cambridge Univ. Press. [ISBN: 9781107013865]

An in-depth technical discussion of typologies of translation techniques prompted by some difficult forms in the Latin translation of a Greek medical text.

Rochette, Bruno. 1997. Le latin dans le monde grec: Recherches sur la diffusion de la langue et des lettres latines dans les provinces hellénophones de l'Empire romain. Brussels: Collection Latomus. [ISBN: 9782870311738]

Chapter 4 of this important book (also cited under *General Overviews*) contains a discussion of Greek translations of Latin literature.

\section{"ROMAN GREEK"}

This topic is a crossover between the epigraphic focus of the regional studies, the literary sections, and the technical linguistic studies that follow. "Roman Greek" is the term used to describe a type of Greek produced by Roman historians and officials under the Empire. See Dubuisson 1979 for an overview of the knowledge of Latin among Greek historians. The best-known example is that of Polybius, thanks to the brilliant study by Dubuisson 1985; see also Ward 2007 for Josephus. Work on the official documents produced for the Greek East has been offered by García Domingo 1979 and Sherk 1969.

Dubuisson, Michel. 1979. Le latin dans les historiens grecs. Les Etudes Classiques 47:89106.

A brief conspectus of the knowledge of Latin among Greek historians. Largely descriptive. Dubuisson, Michel. 1985. Le latin de Polybe. Paris: Klincksieck. [ISBN: 9782865631117]

A phenomenal book discussing in detail the Latinisms of Polybius's Greek. Part 1 offers a detailed exposition of the transposition of "Roman realities" into Greek, showing that Polybius took care to avoid transcription and borrowings from Latin; Part 2 describes and documents the interference of Latin on Polybius's Greek (lexical, phraseological, morphological, and syntactical); Part 3 discusses the historical context.

García Domingo, Enrique. 1979. Latinismos en la koinè (en los documentos epigráficos desde el 212 a. J.C. hasta el 14 d. J.C.): Gramática y léxico griego-latino, latino-griego. Burgos, Spain: Colegio Universitario de Burgos. [ISBN: 9788470090738] A detailed linguistic study of the corpus of Roman official texts (laws, decrees, and senatus consulta) translated into Greek. To be read with Sherk 1969, which provides the epigraphic and historical commentary.

Sherk, Robert K. 1969. Roman documents of the Greek East: Senatus consulta and epistulae to the age of Augustus. Baltimore: Johns Hopkins Univ. Press. 
Well-presented and easy-to-use collection of senatus consulta and epistulae sent to the Greek East during the Republican and Augustan periods, accompanied by detailed commentary. Useful discussion of the style of the Greek employed and what this suggests about the translation and production of the documents.

Ward, Joel S. 2007. Roman Greek: Latinisms in the Greek of Flavius Josephus. Classical Quarterly 57:632-649.

Presents results of searches carried out electronically and by hand to demonstrate the strong, and hitherto underappreciated, influence of Latin on Josephus's Greek in vocabulary and syntax. In contrast, the influence of his native Aramaic is shown to have decreased with time. Three appendixes list the occurrences of specific syntactical features.

\section{TECHNICAL LINGUISTIC STUDIES}

Technical linguistic studies relevant to language contact situations in the Roman world are numerous, though many are relatively narrowly focused. The following major works are split into two loose categories: lexical and non-lexical. Adams 2003 and Adams 2007 (both cited under *General Overviews*) provide sensible discussion throughout on language contact phenomena (lexical and non-lexical) from a range of languages into Latin and vice versa; references are furnished to the key publications on every feature, so the indexes to these works are an excellent place to start.

\section{Lexical Contact-Induced Change (Loanwords)}

Dickey 2012 introduces some of the main lexica in the field. None of the other items is recommended for non-linguists. Binder 2000 and Cervenka-Ehrenstrasser and Diethart 1996 discuss Latin loanwords in Greek. Biville 1990-1995 treats Greek loanwords in Latin. De Vaan 2008 considers some loanwords in Latin and other Italic languages. Nicolas 1996 treats calques (sometimes known as "loan translations").

Binder, Vera. 2000. Sprachkontakt und Diglossie: Lateinische Wörter im Griechischen als Quellen für die lateinische Sprachgeschichte und das Vulgärlatein. Hamburg, Germany: Buske. [ISBN: 9783875482072]

A spectacularly detailed and valuable discussion of the linguistic evolution and complexities of Latin based on the evidence of Latin loanwords in Greek.

Biville, Frédérique. 1990-1995. Les emprunts du latin au grec: Approche phonétique. 2 vols. Louvain, Belgium: Peeters.

Two volumes on the phonetic realization of Greek loanwords in Latin. The first volume offers an introduction and information about consonants; the second, a discussion of vowels and conclusions. Lucid and cautious (though not on Oscan matters). Essential reading on Greek loanwords.

Cervenka-Ehrenstrasser, Irene-Maria, and Johannes M. Diethart. 1996. Lexikon der lateinischen Lehnwörter in den griechischsprachigen dokumentarischen Texten Ägyptens mit Berücksichtigung koptischer Quellen (Lex. Lat. Lehn). Vienna: Hollinek.

A huge undertaking, and as yet unfinished. It is steadily replacing, e.g., Il lessico latino nel greco d'Egitto by Sergio Daris (Barcelona: Institut de Teologia Fonamental, Seminari de Papirologia, 1991). Entries contain translation, citations, variant forms and abbreviations, Latin equivalents, etymologically related words, Greek synonyms, bibliography, and technical discussion.

de Vaan, Michiel A. C. 2008. Etymological dictionary of Latin and the other Italic languages. Leiden Indo-European Etymological Dictionary 7. Leiden, The Netherlands, and Boston: Brill. [ISBN: 9789004167971] 
A valiant attempt to fill a hole in the recent scholarship. Does not include loanwords from known non-Italic languages, but does include loanwords from Sabellic and probable loanwords from unidentifiable, but possibly old Mediterranean, donor languages.

Dickey, Eleanor. 2012. Latin loanwords in Greek: A preliminary analysis. In Variation and change in Greek and Latin. Edited by Martti Leiwo, Hilla Halla-aho, and Marja Vierros, 57-70. Helsinki: Finnish Institute at Athens. [ISBN: 9789526721149]

A basic introduction to some of the problems of identifying loanwords and a good place to read about the issues with some of the previous scholarship.

Nicolas, Christian. 1996. Utraque lingua: Le calque sémantique; Domaine gréco-latin.

Louvain, Belgium: Peeters. [ISBN: 9789068318890]

The only recent book-length treatment of calquing between Greek and Latin.

\section{Non-lexical Contact-Induced Change}

Non-lexical contact-induced change can take a range of forms, e.g., syntactical, phonological, and morphological. This selection gives a flavor of the field. This scholarship is difficult for non-specialists: Coleman 1975; Eska 1987; Leiwo, et al. 2012; and Russell 2011 are the more accessible items. Calboli 2009 and Rubio 2009 are detailed discussions of Latin syntax in Greek and Semitic syntax in Latin and are recommended for specialists only, as is the collection of papers in Kramer 2011.

Calboli, Gualtiero. 2009. Latin syntax in Greek. In New perspectives on historical Latin syntax. Vol. 1, Syntax of the sentence. Edited by Philip Baldi and Pierluigi Cuzzolin, 65193. Berlin and New York: Mouton de Gruyter. [ISBN: 9783110190823]

A huge and important treatment of Latin syntax in Greek.

Coleman, Robert G. G. 1975. Greek influence on Latin syntax. Transactions of the Philological Society 74:101-156.

For a long time the locus classicus, now several points nuanced elsewhere (e.g., Adams $\underline{2003}$ and Adams 2007, both cited under *General Overviews*) but still important.

Eska, Joseph F. 1987. The language of the Latin inscriptions of Pompeii and the question of an Oscan substratum. Glotta 65:146-161.

A clear exposition of the problems with assuming substratum interference demonstrated through the evidence of the so-called Oscan features of the Latin inscriptions of Pompeii.

Kramer, Johannes. 2011. Von der Papyrologie zur Romanistik. Berlin and New York: Mouton de Gruyter. [ISBN: 9783110247022]

A collection of twenty-nine of Kramer's previously published articles. Several papers focus on Latin-Greek contact, including number 5 (on the question of a possible Greek-Latin "Sprachbund"), number 7 (on the phonology of "Vulgar" Latin based on the Greek papryri), and number 9 (the accentuation of Latin loanwords in Greek). Most of the other papers are devoted to the etymology or semantics of lexical forms in the papyri.

Leiwo, Martti, Hilla Halla-aho, and Marja Vierros, eds. 2012. Variation and change in Greek and Latin. Helsinki: Finnish Institute at Athens. [ISBN: 9789526721149]

A volume that bears the marks of conference proceedings, but nonetheless contains some useful papers and most are relevant to our theme: Evans (pp. 25-42) and Vierros (pp. 4356) both treat Egyptian influence on Greek, Dickey (pp. 57-70) discusses loans (see *Lexical Contact-Induced Change [Loanwords]*), Poccetti (pp. 71-96) tackles names from Greek religion and mythology in the languages of Ancient Italy, and Solin (pp. 97-114) treats Greek in Campania.

Rubio, Gonzalo. 2009. Semitic influence in the history of Latin syntax. In New perspectives on historical Latin syntax. Vol. 1, Syntax of the sentence. Edited by Philip Baldi and Pierluigi Cuzzolin, 195-239. Berlin and New York: Mouton de Gruyter. [ISBN: 9783110190823] 
Begins with a useful discussion of the context of Semitic-Latin interaction followed by a comprehensive overview of the evidence divided into manageable sections.

Russell, Paul. 2011. Latin and British in Roman and post-Roman Britain: Methodology and morphology. Transactions of the Philological Society 109:138-157.

A reminder that Insular Celtic languages are a source of Latin. An authoritative survey of the work that has been done already on contact between British Celtic and Latin, followed by an important addition to the debates on methodology and morphological features. 